\title{
THE ROLE OF MUSLIM CLERGY IN COUNTERING RADICAL IDEOLOGY IN THE NORTH CAUCASUS
}

\author{
(C) Muslimat A. Magomedova \\ Daghestan Scientific Centre of Russian Academy of Sciences, Makhachkala, \\ Republic of Dagestan, Russian Federation \\ muslimat-rci@mail.ru
}

Over the past twenty years, state and municipal authorities, civil society institutions in the North Caucasus have gained great positive experience in countering religious extremism and terrorism. The Muslim clergy had a great influence on the socio-political processes in the republics of the North Caucasus. The leadership of the Spiritual Directorates of Muslims of Russia, the traditional Muslim clergy, and ordinary believers have been fighting against the spread of a radical religious ideology that distorts the basis of Islam for more than two decades. Back in the early 90-s, the Islamic newspapers "Assalam", "Nur-ul-Islam", "Islamic Herald" and the Spiritual Board of Muslims began to explain to the population the whole danger of the ideology of Wahhabism (the extreme form of Salafism, which is commonly called in the republics of the North Caucasus). "Wahhabis" in scientific and journalistic literature are considered to be followers of the religious-political current in Sunni Islam, which arose in the middle of the 18th century based on the teachings of Muhammad ibn Abd al-Wahhab. Many modern followers of Wahhabism prefer to call themselves Salafiyun, i.e. "walking the path of righteous ancestors" (al-salaf al-salih) - the first generations of Muslims. The article sets the task of analyzing the effectiveness of ideological counteraction to religious extremism and terrorism in the North Caucasus, determining the role of representatives of the Muslim clergy in countering radical religious ideology. The main theological contradictions between the trends in Islam are analyzed. It is shown that representatives of the Muslim clergy play a significant role in the ideological opposition to religious extremism in the North Caucasus. youth.

Key words: North Caucasus, Islam, religious and political extremism, religious extremism, Wahhabism,

\section{[M.A. Магомедова Роль мусульманского духовенства в противодействии радикальной идеологии на Северном Кавказе]}

За последние двадцать лет государственные и муниципальные органы власти, институты гражданского общества на Северном Кавказе накопили большой положительный опыт по противодействию религиозному экстремизму и терроризму. Большое влияние на общественно-политические процессы в республиках Северного Кавказа оказало мусульманское духовенство. Руководство Духовных управлений мусульман России, традиционное мусульманское духовенство, рядовые верующие вот уже более двух десятилетий ведут борьбу против распространения радикальной религиозной идеологии, искажающей основу ислама. Еще в начале 90-х гг. исламские газеты «Ассалам», «Нур-ул-Ислам, «Исламский вестник» и Духовное управление мусульман (ДУМ) начали разъяснять населению всю опасность идеологии ваххабизма (крайняя фрорма салафизма, которую так принято называть в республиках Северного Кавказа). «Ваххабитами» в научной и публицистической литературе принято считать последователей религиозно-политического течения в суннитском исламе, возникшего в середине XVIII в. на основе учения Мухаммада ибн Абд аль-Ваххаба. Многие современные последователи ваххабизма предпочитают называть себя салафийун, т.е. «идущими по пути праведных предков» (ас-салафф ас-салих) - первых поколений мусульман. В статье поставлены задачи анализа эффективности идеологического противодействия религиозному экстремизму и терроризму на Северном Кавказе; определения роли представителей мусульманского духовенства в противодействии радикальной религиозной идеологии. Проанализированы основные теологические противоречия между течениями в исламе. Показано, что значительную роль в идеологическом противодействии религиозному экстремизму на Северном Кавказе играют представители мусульманского духовенства.

Ключевые слова: Северный Кавказ, ислам, религиозно-политический экстремизм, религиозный экстремизм, ваххабизм, молодежь. 
Muslimat A. Magomedova - Ph.D. in Philosophy, Senior Research Fellow, Regional Centre of Ethnopolitical Researches, Daghestan Scientific Centre of Russian Academy of Sciences, Makhachkala, Republic of Dagestan, Russian Federation.

Магомедова Муслимат Алхилаевна - кандидат фрилософских наук, старший научный сотрудник, $\mathrm{Pe-}$ гиональный чентр этнополитических исследований Дагестанского федерального исследовательского центра Российской академии наук, г. Махачкала, Республика Дагестан, Российская Федерация.

Over the past few decades, we can observe a revival of religion in the whole country. These are objective processes. People got the opportunity to freely receive any religious education. As an example, teaching children, youth, and part of the adult population about Islam is widespread, in the Republic of Dagestan. Now the main task of the authorities, the muftiat and society is to ensure that these processes do not acquire a radical character, but carry ideas of peace, spirituality, love, mercy and forgiveness, mutual respect, as well as respect for parents and representatives of other faiths.

The method of in-depth interviews and questionnaires of experts were used to identify assessments of the effectiveness of ideological counteraction to religious extremism and terrorism in the region and to determine the role of the Muslim clergy in countering radical religious ideology. The experts were professionals who are involved in the problems of ideological counteraction to extremism and terrorism.

Russia is the leader in the number of Islamic universities in the post-Soviet space. According to the Ministry of Justice, in April 2018, 78 Muslim educational institutions were registered, 25 of which are considered higher, and 53 are secondary schools (madrassas). Most of them are in the North Caucasus [6].

The greatest influence of religion on various spheres of public life can be noted in such subjects of the North Caucasus as the Republic of Dagestan, the Chechen Republic and Ingushetia.

As at August 1, 2019, 2671 functioning religious buildings in Dagestan are: Islamic 2631 (6 are universities, which teach 917 people, and 15 madrassas (955 people), jumah mosques (1273), mosques (899), prayer houses (437), Islamic Youth Union (1)), Christian 33 (of them Orthodox - 23, Protestant - 8, Armenian Apostolic Church - 1, Old Believers 1), Jewish - 5 [9].

The structure of religious education in Dagestan includes maktabs (mosque-based elementary schools), madrassas (secondary vocational education) and Islamic universities and institutes (higher level).

According to the Minister of National Policy and Religious Affairs of the Republic of Dagestan, the total number of Dagestanis who have received Islamic education abroad from 1990 to the present is more than 1250 people [7].

The religious media of the North Caucasus republics are represented by the press of various faiths. Internet resources of a religious and educational nature are actively developing. Considerable attention is paid to Islamic issues on television and radio channels, which broadcast religious programs in Russian and native languages.

Religion began to occupy a significant place in the life of the community of the Chechen Republic, especially during its revival after the military-political conflict and anti-terrorist operations. 1060 large and small mosques operate in the republic today. The Russian Islamic University Kunta-haji Kishiev, Islamic Institute named after Akhmat-Haji Kadyrov, 20 madrassas and 4 of their branches, 6 schools of hafiz (reciters of the Quran by heart) form religious educational resource [10]. 
The process of organizational change, the development of social projects of the future from the perspective of Islam began after the collapse of the USSR in the 90-s. During the process, that separate both opposing currents of tariffication and Wahhabism began to take shape. During this process, separate and opposing flows Tariqah and Wahhabism started to form. Wahhabism was introduced to the North Caucasus in the late $80-\mathrm{s}-$ early $90-\mathrm{s}$ of the 20 century by some graduates of foreign Islamic educational institutions and missionaries from the Arabic-speaking countries. A certain part of the representatives of Salafism with the help of religious slogans tried to justify the need for a violent change in the constitutional system, the creation of a Sharia state.

Tariqah refers to the socio-political activity of religious figures associated with Sufi brotherhoods, the so-called Tariqas. Sufi ideology and practice penetrated, for example, in Dagestan back in the 10-11 centuries [5].

For several reasons, several decades after the death of Muhammad, several large religious and political groups formed in Islam, which, in turn, split into many schools and communities [8, p. 22]. The followers of the earliest religious and political group in the history of Islam, formed during the struggle for power, were the Kharijites.

Disputes over the succession of supreme power after the death of Muhammad gave rise to the first differences among Muslims. A brief summary of subsequent events in the earIy Islamic community until the reign of Ali and the beginning of the Kharijit movement serves as a preface to the description of the teachings and discrepancies among Muslims [8, $p$. 128].

The followers of the region's traditional Islam do not accept not only Wahhabi ideology and practice of religious rites, but also their lifestyle, behavioral and cultural attitudes, denial of respect for elders, rejection of Caucasian customs and traditions. Because of this, the conflict between "North Caucasian Wahhabism" and Sufism has not only a dogmatic, ideological character, but also a sociocultural orientation, which is manifested in the mutual rejection of the lifestyle, behavioral attitudes, cultural values inherent in them [3, p. 154].

The main reasons that led to hostility, Wahhabis believe that many Muslims were in delusion, lived in sin and were far from the direct path. The second reason is that they consider that the enemies of Islam began to make false accusations and spread vile slander against sheikh Muhammad Ibn Abd al-Wahhab and his supporters. The third reason was the political tensions and wars that broke out between the followers of the call on the one hand and the Turks and emirs of the provinces on the other. The fourth reason was the accumulation of hostile literature.

Modern followers of Wahhabism believe that Muslims have lost their way because they overly venerate the Prophet Muhammad; prohibit collective dhikr (commemoration of Allah); deny the madhhabs (religious schools in Islam); deny Sufism, ridiculing the teachings of one of the revered Sufis of Imam al-Ghazali; deny the worship of graves or other "sacred" monuments (ziyarat). All of the above, in their opinion, leads Muslims to shirk (polytheism).

Also in these Islamic ideological movements, concepts such as jihad and shahid are considered in different ways. In Muslim religious and political culture, the term "shahid" refers to a Muslim who sacrificed himself for his faith and accepted martyrdom. However, Islamic orthodoxy categorically denies the identity between "shahid" and suicide bombers.

Today, there are certain tricks that allow a person who has expressed a willingness to die a martyr's death to bring into a state from which there is no way back. He is told that he was created and lives to serve God. Life is only a means of serving God. Jihad (Holy War) is unconditional service to God, and death as a result of Jihad is the climax of such service. For Muslims, there is no goal higher than life in the name of Allah and death for him [4, p. 166]. On this occasion, one of the experts during the interview noted:

"There is a certain postulation of extremist ideas through the refraction of the Koran. There is no retrospective analysis, but there is a parallel translation of these verses to the 
present. Translation of the Koran without knowledge, analytical philosophy. Moreover, who is eventually charged with this virus, it is already difficult for him to get out of this state. It is difficult because they introduce them there through the factor of sacredness, sacralization of God."

According to the expert, true knowledge that is sufficiently adapted is adequate in the situation in which we live is concentrated in the muftiate.

Islamic extremism holds and develops on a carefully developed ideological basis, the power of extremism lies in the mobilizing power of slogans.

In the official List of organizations and individuals for which there is information about their involvement in extremist activities or terrorism, Dagestanis are ahead of other Muslim regions by a wide margin. If we take data for 2013-2016, 32.6\% of the natives of Dagestan, $8.7 \%$ of the Chechen Republic, $5.4 \%$ of Kabardino-Balkaria, 1.4\% of Ingushetia, this indicator was the lowest in Tatarstan - 1.1\%. In the updated list, which was published in the "Rossiyskaya Gazeta" in early 2019, Dagestanis already 38.3\% [2].

During the confrontation between representatives of traditional Islam and Salafis in Dagestan, dozens of religious figures from both sides were killed. Representatives of the traditional Muslim clergy in their sermons emphasized that the preachers of radical religious ideology, under the guise of reasoning about the welfare of the people, pursue goals that diverge from the true tenets of Islam, and kindle a bonfire of ethnic hatred. Nevertheless, some scholars argue that the official Muslim clergy in the North Caucasus did not pay due attention to the issue of theoretical and ideological opposition to terrorism under the guise of Islam in its most acute form for a long time. At the same time, they claim that more than 50 ministers of the Muslim cult died at the hands of terrorists [4, p. 175]. In our opinion, despite all the danger, religious figures from the very beginning of the spread of radical religious ideology in Dagestan realized what it would turn out for people and society and took effective measures, criticized the authorities for their loyal attitude towards the Salafists.

Islam has everything in order to provide society with a non-conflict system of values that will ensure the intensive development of society. It was the time of the Golden Age of the Caliphate, when Muslims, with all their practice, with their whole way of life, set the tone for the development of human civilization. It was the Muslims who gave the development of astronomy, medicine, and mathematics.

In the course of the expert survey, which was mentioned above, the respondents were asked an open question: "What role do you think representatives of the clergy of the republic play in the ideological opposition to religious and political extremism?" and it was proposed to evaluate in points on a scale from 0 to 10.

As a result of the study, high assessments of the activities of representatives of the clergy of the North Caucasian republics in ideological opposition to religious and political extremism were obtained. The average score was above 8 points.

According to most experts, Islamic religious figures play a major role in society in the matter of ideological opposition to destructive ideology. They fill the niche that was created after the collapse of the USSR in ideological terms.

An analysis of expert interviews reveals several key points of view. Some experts say that religious leaders of traditional Islam have done a tremendous amount of work in the direction of ideological opposition. The spiritual leader of the Muslims of Dagestan, Said-Afandi Chirkey, in this regard played the biggest role. Below are some expert comments.

- Representatives of the clergy perform explanatory work; are at the forefront of opposition, influence through sermons, speeches in the media, participation in various events at the place of residence; religious lectures are held on the formation of the spiritual and legal culture of young people, introducing into the student environment the practice of norms of tolerant behavior; constantly offer new forms of cooperation and interaction. 
- In many cases and in certain issues, the opinion and position of authoritative theologians is key for most citizens, since the ideas of extremism are mainly presented on religious grounds.

Other experts claim that official Islam in the North Caucasus, represented mainly by the Spiritual Directorates of Muslims, also contributed to the spread of religious extremism. The Spiritual Administration of Muslims of Dagestan failed to unite all Islamic communities of Dagestan in a national context. This disunity resulted in a confrontation known in religious circles with mutual accusations. It is one of the factors weakening the opposition to religious terrorism in the republic: in the system of religious communities of Dagestan there is no single organizing, coordinating, legitimate center. The reason for this is the ambitions of Muslim leaders [1].

In particular, the following expert comments can be cited:

- Representatives of the clergy are preoccupied with their own problems of confessional exclusiveness.

- Our intra-confessional society is split. There are Muslims who support the official clergy; there are those who categorically do not accept them. This problem is formed by both subjective and objective reasons.

- The official Islamic clergy have a dual role. For example, somewhere there is a Salafi mosque, somewhere there are structures that do not want to work with traditional Islam, the Muftiate, and they crush them. There were big problems in the Kizlyar district, in the Khasavyurt district of Dagestan. The so-called traditionalists closed these mosques through the Ministry of Internal Affairs. In this regard, they play a negative role. The Muftiyats have little cooperation with religious figures close to the Salafis, they cannot find a common language. In this regard, the muftiate plays a negative role. In terms of the fact that they united the diverse mass under traditional Islam, they play a very large role in the unification of Dagestan society.

In the 90-s, in some republics of the North Caucasus, religious organizations merged with the state. The state delegated to public organizations part of its state functions. Expert opinion on religious publications. In addition, it turns out that the public organization began to issue an opinion on the books that were published by other public organizations. This is the prerogative and duty of the state as a judge, arbitrator over them. Therefore, a kind of split occurred due to the resources provided by the state.

In any case, if we talk about the positive role of the clergy, then their contribution is very high. Several dozen people died only because they called for good. However, it is important that they should not go too far. Because if they begin to play too independent role working too closely with the state, too actively defending the interests of their Tariqi group, they push others away from this process.

- Now official Islam (Sufism) is being politicized.

- I consider it insufficient, there are not enough competent alims who can convey the main canons of Islam to young people.

According to experts, among the dominant reasons for involving young people in extremist ideology is the lack of an alternative ideology. To the question "How do you assess the effectiveness of ideological opposition to religious extremism in your region?", the average rating score on a ten-point scale was about 7 points.

The expert opinion was divided as follows.

1. There is no core ideological opposition.

In our opinion, this can be justified by the fact that the Constitution of the Russian Federation provides for the pluralism of ideologies.

The fragile minds of the ideologists of religious extremism are mainly influenced by religious identity, arguing that Muslims should not live in a non-Muslim state and serve it. In this regard, one can note the omissions of representatives of the Muslim clergy in working with 
youth. It is advisable to conduct explanatory work with young people that they are obliged to comply with the laws of that state, which does not prevent them from fulfilling all the requirements of their religion.

2. Work on ideological counteraction to religious and political extremism is conducted inefficiently. All activities in this area are focused not on advancing and prevention, but on eliminating the consequences. There is a quote from one of the experts.

"On the one hand, large-scale work is being carried out on ideological prevention. Nobody can compare with Chechnya with the number of events and people involved. Therefore, every Chechen schoolchild or student knows exactly how the state and government relate to this ideology, and what punishment he / she expects in case of participation.

However, these efforts are mostly extremely formal, non-creative, frankly boring. Religious figures during such events usually praise the authorities, which discredits them in the eyes of young people. Young people do not perceive the opinion of the Chechen clergy as independent and objective. Often, lectures on prevention have a rather aggressive and threatening tone. Given the ambiguous attitude of the population towards power, such a massive attack can be counterproductive, it, on the contrary, touts this ideology. For some young people (especially those who have loved ones who died), direct and rather aggressive counter-propaganda promotes the heroization of ultra-radical groups."

Many experts noted that ideological opposition should be based on Islam, on highly educated Muslim religious leaders. For young people are introduced into radical Islam precisely through the misinterpreted verses of the Quran.

$M$. Chernov, an expert on interethnic relations and inter-religious dialogue, the head of the Middle East-North Caucasus project, said that the most effective method of combating the ideology of extremism and terrorism is real and sincere Islam, and stressed that in Dagestan the muftiate has achieved impressive success in this paths [11].

The main part of ideological prevention should be explanatory, enlightening and educational work. A significant problem of involving young people in radical ideology is religious ignorance.

We need targeted work with people who are infected with radical religious ideas and are on the wrong track. Analyzing the reasons for the spread of the ideology of religious and political extremism in the republics of the North Caucasus, it can be argued that if social injustice is not eliminated, if conditions for the realization of youth are not created, and if the enormous gap between rich and poor people is not eliminated, a social explosion can occur. For those colour revolutions (the "orange revolution" in Ukraine, the "rose revolution" in Georgia, etc.) relied on disgruntled youth through social networks. Moreover, according to the interviewed responding teachers, the majority of young people who go to educational institutions show low results in terms of preparedness. Preachers of radical Islam manipulate these social problems, present them in terms of injustice and urge young people to take radical measures.

The subjects of the North Caucasus are developing their own programs to counter extremist and terrorist ideology.

Opposition to the ideology of religious extremism should include a set of organizational, socio-political, information and propaganda measures to prevent the spread in society of beliefs, ideas, moods, and motives, attitudes aimed at fundamentally changing the existing social and political institutions of the state.

\section{Лumepamypa}

1. Абдулагатов 3.М. Послание президента РД: новый взгляд на проблему терроризма // Актуальные проблемы противодействия религиозно-политическому экс- 
тремизму: материалы Всероссийской научно-практической конференции. Махачкала: Лотос, 2007. С. 269-273.

2. Абдулагатов 3. У нас экстремизм путают с мусульманским образом жизни // [Электронный ресурc]. URL: https://md-gazeta.ru/obshhestvo/71761 (дата обращения: 27.05.2019).

3. Акаев В.X. Суфийская культура на Северном Кавказе: теоретические и практические аспекты / отв. ред. Г.В. Драч. Изд. 2-ое, перераб. и доп. Грозный: Книжное издательство, 2011. 208 с.

4. Добаев И.П., Добаев А.И., Немчина В.И. Геополитика и терроризм эпохи постмодерна. Ростов-на-Дону: Изд-во ЮФУ, 2015. 370 с.

5. Кисриев Э. Идеологический смысл и социальное содержание исламских течений тарикатизма и ваххабизма в Дагестане // Ислам в Европе и в России: сб. статей /сост. и отв. ред. Е.Б. Деминцева. М.: Изд. дом Марджани, 2009. С. 182-200.

6. Муртазин М.Ф. О проблемах развития исламского образования на постсоветском пространстве // Ислам и исламоведение в современной России: сборник докладов Всероссийского исламоведческого форума / под общей редакцией профессора М.Я. Яхъяева. Махачкала: АЛЕФ, 2019. С. 436-443.

7. Муслимов Э.С. Исламское образование в Дагестане: состояние и перспективы // Ислам и исламоведение в современной России: сборник докладов Всероссийского исламоведческого фрорума / под общей редакцией профессора М.Я. Яхъяева. Махачкала: АЛЕФ, 2019. С. 426-430.

8. Прозоров С.М. Ислам как идеологическая система. СПб, М.: Вост. лит., 2004. 471 c.

9. Раджабов Х.М., Магомедов М.Ю. Роль конфессиональных массмедиа в информационно-просветительской работе в Республике Дагестан // Ислам и исламоведение в современной России: сборник докладов Всероссийского исламоведческого форума / под общей редакцией профессора М.Я. Яхъяева. Махачкала: АЛЕФ, 2019. С. 345-349.

10.Юсупов М.М. Межконфессиональные и религиозные отношения в Чеченской Республике // Состояние межэтнических отношений и этноконфессиональная ситуация в субъектах РФ Северо-Кавказского федерального округа. Второе полугодие и итоги 2017 года / научн. консультат В.А. Тишков; отв. ред. М.А. Аствоцатурова. Экспертный доклад. Научное издание. Пятигорск: ПГУ, 2017. С. 171-176.

11. Эксперт: Муфтият Дагестана добился впечатляющих успехов [Электронный реcypc] URL: http://islamdag.ru/node/51947 (дата обращения: 28.08.2019).

\section{References}

1. Abdulagatov Z.M. Poslaniye prezidenta RD: novyy vzglyad na problemu terrorizma. Aktualnyye problemy protivodeystviya religiozno-politicheskomu ekstremizmu: materialy Vserossiyskoy nauchno-prakticheskoy konferentsii. [Abdulagatov Z.M. Message from the President of the Republic of Dagestan: a new look at the problem of terrorism. Actual problems of counteracting religious and political extremism: materials of the All-Russian Scientific and Practical Conference]. Makhachkala: Lotus, 2007. pp. 269-273 (In Russian).

2. Abdulagatov Z. $U$ nas ekstremizm putayut $s$ musulmanskim obrazom zhizni. [We have confused extremism with the Muslim way of life]. Available at: https://mdgazeta.ru/obshhestvo/71761 (accessed 27 May 2019) (In Russian). 
3. Akayev V.Kh. ufiyskaya kultura na Severnom Kavkaze: teoreticheskiye i prakticheskiye aspekty. [Sufi culture in the North Caucasus: theoretical and practical aspects]. Groznyy: GUP Knizhnoye izdatelstvo. 2011. 208 p. (In Russian).

4. Dobaev I.P., Dobaev A.I., Nemchina V.I. Geopolitika i terrorizm epokhi postmoderna. [Geopolitics and terrorism of the postmodern era]. Rostov-na-Donu: Izd-vo SFedU, 2015. 370 p. (In Russian).

5. Kisriev $E$. Ideologicheskiy smysl i sotsial'noye soderzhaniye islamskikh techeniy tarikatizma i vakhkhabizma $v$ Dagestane. Islam $v$ Yevrope i $v$ Rossii. [The ideological meaning and social content of Islamic trends of tarikatism and Wahhabism in Dagestan. Islam in Europe and in Russia]. Moscow: Mardzhani, 2009. pp. 182-200. (In Russian).

6. Murtazin M.F. O problemakh razvitiya islamskogo obrazovaniya na postsovetskom prostranstve. Islam i islamovedeniye v sovremennoy Rossii: sbornik dokladov Vserossiyskogo islamovedcheskogo foruma. [On the problems of the development of Islamic education in the post-Soviet space. Islam and Islamic studies in modern Russia: a collection of reports of the All-Russian Islamic Studies Forum]. Makhachkala: ALEF, 2019. pp. 436-443 (In Russian).

7. Muslimov E.S. Islamskoye obrazovaniye v Dagestane: sostoyaniye i perspektivy. Islam i islamovedeniye $\mathrm{v}$ sovremennoy Rossii: sbornik dokladov Vserossiyskogo islamovedcheskogo foruma. [Islamic education in Dagestan: state and prospects. Islam and Islamic studies in modern Russia: a collection of reports of the All-Russian Islamic Studies Forum]. Makhachkala: ALEF, 2019. pp. 426-430 (In Russian).

8. Prozorov S.M. Islam kak ideologicheskaya sistema. [Islam as an ideological system]. Moscow, 2004. 471 p. (In Russian).

9. Radjabov H.M., Magomedov M.Yu. Rol konfessionalnykh massmedia v informatsionnoprosvetitelskoy rabote $v$ Respublike Dagestan. Islam i islamovedeniye $v$ sovremennoy Rossii: sbornik dokladov Vserossiyskogo islamovedcheskogo foruma. [The role of confessional mass media in outreach in the Republic of Dagestan. Islam and Islamic studies in modern Russia: a collection of reports of the All-Russian Islamic Studies Forum]. Makhachkala: ALEF, 2019. pp. 345-349 (In Russian).

10. Yusupov M.M. Mezhkonfessionalnyye i religioznyye otnosheniya v Chechenskoy Respublike. Sostoyaniye mezhetnicheskikh otnosheniy i etnokonfessional'naya situatsiya v subjektakh RF Severo-Kavkazskogo federal'nogo okruga. Vtoroye polugodiye i itogi 2017 goda. Ekspertnyy doklad. Nauchnoye izdaniye. [Interfaith and religious relations in the Chechen Republic. The state of interethnic relations and the ethno-confessional situation in the constituent entities of the Russian Federation of the North Caucasus Federal District. Second half year and results of 2017. Expert report. Scientific publication]. Pyatigorsk: PGU, 2017. pp. 171-176 (In Russian).

11. Ekspert: Muftiyat Dagestana dobilsya vpechatlyayushchikh uspekhov. [Expert: Muftiyat of Dagestan has achieved impressive success]. Available at: http://islamdag.ru/node/51947 (accessed 28 August 2019) (In Russian). 